\title{
Energy expenditure in dogs before and after body weight reduction
}

\author{
Caroline Larsson ${ }^{1 *}$, Anne Vitger ${ }^{1}$, Rasmus Bovbjerg Jensen ${ }^{1}$, Peter Junghans ${ }^{1}$, Anne-Helene Tauson ${ }^{1,2}$ \\ From Animal Obesity - causes, consequences and comparative aspects \\ Uppsala, Sweden. 14-16 June 2015
}

\section{Introduction}

Regain of body weight (BW) after a successful BW reduction program is a common problem. It has been discussed whether or not the maintenance energy requirement changes with reduced BW in dogs.

\section{Objective}

The objective with this study was to investigate the impact of BW reduction and changes in body composition on the energy expenditure (EE) when measured under conditions corresponding to the basal metabolic rate (BMR).

\section{Material and methods}

The EE in five privately owned, overweight dogs was measured by indirect calorimetry. Two measurements per dog were performed under the same standardised conditions (i.e. fasted and resting state) at the start, and after completing a 12 -week $\mathrm{BW}$ reduction program including exercise and dietary restriction. Additionally, measurements of body composition by Dual-energy $\mathrm{X}$-ray absorptiometry (DEXA) were conducted at the beginning and at the end of the BW reduction program.

\section{Results}

The dogs lost 16\% (SD \pm 2.0 ) of their initial BW. Their fat mass was reduced $(p<0.001)$, whereas fat free mass (FFM) remained unchanged. The EE decreased $(\mathrm{p}<0.001)$ with reduced BW from $4231 \mathrm{~kJ} / \mathrm{d}$ at the start, to $3511 \mathrm{~kJ} / \mathrm{d}$ at the end measurements. However, there was no effect of the $\mathrm{BW}$ reduction on the determined EE expressed in $\mathrm{kJ} / \mathrm{kg}$

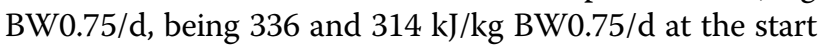
and end measurements, respectively.

\footnotetext{
* Correspondence: cala@sund.ku.dk

'Department of Veterinary Clinical and Animal Sciences, University of Copenhagen, Copenhagen, Denmark

Full list of author information is available at the end of the article
}

\section{Conclusion}

The results suggest that the BMR does not change with reduced BW in overweight dogs as long as the FFM remains unchanged.

\section{Authors' details}

'Department of Veterinary Clinical and Animal Sciences, University of Copenhagen, Copenhagen, Denmark. ${ }^{2}$ Department of Animal Nutrition and Management, Swedish University of Agricultural Sciences, Uppala, Sweden.

Published: 25 September 2015

doi:10.1186/1751-0147-57-S1-019

Cite this article as: Larsson et al:: Energy expenditure in dogs before and after body weight reduction. Acta Veterinaria Scandinavica 2015 57(Suppl 1):019.

\section{Submit your next manuscript to BioMed Central and take full advantage of: \\ - Convenient online submission \\ - Thorough peer review \\ - No space constraints or color figure charges \\ - Immediate publication on acceptance \\ - Inclusion in PubMed, CAS, Scopus and Google Scholar \\ - Research which is freely available for redistribution \\ Submit your manuscript at www.biomedcentral.com/submit}

